\title{
Methane and Carbon Dioxide Emissions from Different Composting Periods
}

\author{
Cheng-Hsiung Chang, I-Chu Chen, and Shang-Shyng Yang* \\ Institute of Microbiology and Biochemistry, and Department of Biochemical Science and Technology, National Taiwan University, \\ Taipei 10617, Taiwan, ROC
}

Received 22 July 2007, accepted 20 May 2008

\begin{abstract}
To investigate greenhouse gas emissions from compost preparations, methane and carbon dioxide concentrations and emission rates at different accumulative times and composting periods were determined. While the accumulative time was less than 10 min with a closed acrylic chamber, methane and carbon dioxide emissions increased slightly but with high fluctuation in the sampling error, and these values decreased significantly when the accumulative time was more than 20 min. During the 8 weeks of composting, the methane emission rate reaches its peak near the end of the second week and the carbon dioxide emission rate does the same near the end of third week. Methane and carbon dioxide emissions had high values at the first stage of composting and then decreased gradually for the maturity of compost. Carbon dioxide emission (y) was significantly related to temperature $\left(\mathrm{x}_{1}\right)$, moisture content $\left(\mathrm{x}_{2}\right)$, and total organic carbon $\left(\mathrm{x}_{3}\right)$; and the regression equation is: $\mathrm{y}=3.11907 \mathrm{x}_{1}+$ $6.19236 \mathrm{x}_{2}-6.63081 \mathrm{x}_{3}-50.62498$. The regression equation between methane emission $\left(\mathrm{y}^{\prime}\right)$ and moisture content $\left(\mathrm{x}_{2}\right), \mathrm{pH}\left(\mathrm{x}_{4}\right)$, $\mathrm{C} / \mathrm{N}$ ratio $\left(\mathrm{x}_{5}\right)$, and ash content $\left(\mathrm{x}_{6}\right)$ is: $\mathrm{y}^{\prime}=0.13225 \mathrm{x}_{2}-0.97046 \mathrm{x}_{4}-1.10599 \mathrm{x}_{5}-0.55220 \mathrm{x}_{6}+50.77057$ in the initial composting stage (weeks 1 to 3); while, the equation is: $\mathrm{y}^{\prime}=0.02824 \mathrm{x}_{2}-0.0037 \mathrm{x}_{4}-0.1499 \mathrm{x}_{5}-0.07013 \mathrm{x}_{6}+4.13589$ in the later composting stage (weeks 4 to 8 ). Different stage composts have significant variation of properties and greenhouse gas emissions. Moreover, the emissions may be reduced by manipulating the proper factors.
\end{abstract}

Key words: Greenhouse gases, Compost, Emission rate, Accumulative time, Composting period

Citation: Chang, C. H., I. C. Chen, and S. S. Yang, 2009: Methane and carbon dioxide emissions from different composting periods. Terr. Atmos. Ocean. Sci., 20, 511-520, doi: 10.3319/TAO.2008.05.20.01(A)

\section{INTRODUCTION}

Global warming has become a matter of public concern over the last few years. Waste treatment accounts for about $10-19 \%$ of annual methane global emissions into the atmosphere (Bogner et al. 1999; IPCC 2001) and is a significant contributor to global warming in greenhouse gas scenarios. On-farm agricultural practices account for almost $10 \%$ of anthropogenic greenhouse gas emissions and manure accounts for approximately $20 \%$ of total methane emissions from agriculture in Taiwan (Yang et al. 2003a, b, 2005; Yang 2005b). Methane is generated from composting of livestock wastes through degradation of soluble lipids, carbohydrates, organic acids and proteins (Khan et al. 1997), and contributes $5-30 \%$ to the total emission of methane (Sommer and Møller 2000; Külling et al. 2002). The global warming

\footnotetext{
* Corresponding author

E-mail: ssyang@ntu.edu.tw
}

potential of methane is 23 times higher than that of carbon dioxide and atmospheric methane concentration has been increasing at a rate of $-0.2-1 \% \mathrm{yr}^{-1}$ (IPCC 2001; USEPA 2002; Simpson et al. 2006). The primary sources of these emissions are wetlands, enteric fermentation, chemical fertilizers, paddy fields, landfills, and manure management (Chang and Yang 2003; Hegde et al. 2003; Yang et al. 2003a, b; Yang 2005a, b; Chen et al. 2008).

Compared to wetlands and rice fields, composting functions as bioreactor to control and manage biodegradable organic materials (Bogner et al. 1999). These organic materials are decomposed via a complex series of microbial reactions under aerobic and anaerobic conditions. Eventually, they are converted into $\mathrm{CO}_{2}, \mathrm{CH}_{4}, \mathrm{~N}_{2} \mathrm{O}$, and $\mathrm{H}_{2} \mathrm{O}$ (Hao et al. 2001, 2004). Methane and carbon dioxide emissions in composting are mainly influenced by management, temperature, turning, aeration, height, composition, density, moisture con- 
tent and $\mathrm{pH}$ of the raw materials (Osada et al. 2000; Sommer and Møller 2000; Amon et al. 2001; Su et al. 2003; Yang 2005a). Methanogenesis in composting occurs when the organic waste $\mathrm{pH}$ is between 6.8 and 7.4 and is stimulated by increasing moisture content (Jang and Yang 2001).

Although there are many reports available about methane and carbon dioxide emissions from landfills (Hegde et al. 2003; Kumar et al. 2004; Meraz et al. 2004; Chen et al. 2008), compost piles (Fukumoto et al. 2003) and compost windrows (Hao et al. 2001, 2004; Jäckel et al. 2005; Pattey et al. 2005), relatively little work has been done with methane and carbon dioxide emissions from compost plant operations. Previously, small compost equipments, reactor vessels and piles have been utilized to examine the discharge of greenhouse gases during the composting process (Kuroda et al. 1996; Osada et al. 2000; Ekinci et al. 2002; Fukumoto et al. 2003). Organic solid waste releases relatively very high concentrations of greenhouse gases, when actively degraded and metabolized by aerobic and anaerobic microbes in a composting ecosystem; and Lindau et al. (1993) also adapted different sampling times for summer (15 min) and winter (60 min) due to changes in emission rates.

In sum, there is a need for better estimations of greenhouse gases emissions and development of abatement techniques, especially in the area of methane and carbon dioxide emissions produced during the handling of animal manures and agricultural wastes. In this paper, we report methane and carbon dioxide emissions from compost at different accumulative times and composting periods. The correlations between greenhouse gases emissions and properties of composts are also investigated.

\section{MATERIALS AND METHODS}

\subsection{Compost Plant}

This study was conducted at Chian-I Compost Plant in Taoyuan County of northern Taiwan, which produced $1.3 \times$ $10^{4}$ ton of compost per year. The compost plant had 6 tanks (length $80 \mathrm{~m}$, width $6 \mathrm{~m}$ and height $1 \mathrm{~m}$ ) with automatic turning once every 3 - 4 days during 8 weeks of composting. The raw materials were chicken manure $30 \%$, cow manure $20 \%$, food processing residue $20 \%$, sawdust $20 \%$, and wool waste $10 \%$. Samples were collected at each measuring point from a depth of $20 \mathrm{~cm}$ below the surface. The material was mixed well and sieved through 4-mm mesh.

\subsection{Gases Sampling and Measurement}

Atmospheric methane and carbon dioxide in the compost plant were collected using the gas replace method and analyzed by gas chromatography. Gas samples $(35 \mathrm{ml})$ were collected from the atmosphere at each sampling site and transferred to a $12.6-\mathrm{ml}$ serum bottle sealed with a butyl rubber stopper that previously flushed with oxygen-free nitro- gen gas (Yang and Chang 1997). The gas (1.0 ml) was withdrawn and $0.5 \mathrm{ml}$ was injected into the gas chromatograph. Methane was analyzed by a Shimadzu 14A gas chromatograph (Shimadzu Co., Japan) with a glass capillary column $(0.26 \mathrm{~mm} \times 2 \mathrm{~m})$ packed with Porapak Q $(80 / 100 \mathrm{mesh})$ and a flame ionization detector. The column temperature was set at $100^{\circ} \mathrm{C}$, the injection and the detector temperatures were set at $130^{\circ} \mathrm{C}$. Methane concentration was calculated with a standard curve from 0.1 to $100 \mathrm{mg} \mathrm{kg}^{-1}\left(\mathrm{v} \mathrm{v}^{-1}\right)$ with a detection limit of $0.01 \mathrm{mg} \mathrm{kg}^{-1}\left(\mathrm{v} \mathrm{v}^{-1}\right)$ (Yang and Chang 1997). For carbon dioxide analysis, a thermal conductivity detector was used. The column temperature was set at $150^{\circ} \mathrm{C}$, the injection and the detector temperatures were set at $200^{\circ} \mathrm{C}$. Carbon dioxide concentration was calculated using a standard curve from 0.1 to $1000 \mathrm{mg} \mathrm{kg}^{-1}\left(\mathrm{v} \mathrm{v}^{-1}\right)$ with a detection limit of $0.05 \mathrm{mg} \mathrm{kg}^{-1}\left(\mathrm{v} \mathrm{v}^{-1}\right)$ (Chang and Yang 2003).

\subsection{Methane and Carbon Dioxide Emission Rates}

Gas samples were collected using a homemade closed acrylic chamber (length $40 \mathrm{~cm}$, width $40 \mathrm{~cm}$ and height $65 \mathrm{~cm}$, about 96) that was equipped with an electronic fan, a thermometer and a sampling hole (Fig. 1a). For measuring methane and carbon dioxide emission rates, eight acrylic chambers were installed on the surface of composts at different composting periods along a linear path in each measurement. The chambers were inserted into the compost to a depth of $5 \mathrm{~cm}$ and allowed to equilibrate for $10 \mathrm{~min}$ before each measurement (Fig. 1b). Gas samples ( $35 \mathrm{ml})$ were collected from the headspace of each chamber and transferred to a $12.6-\mathrm{ml}$ serum bottle sealed with a butyl rubber stopper that was previously flushed with oxygen-free nitrogen gas. Gas samples were collected from chamber at $0,5,10,15,20,30,40$, and $50 \mathrm{~min}$. Entire sampling process was repeated after three hours for comparison. Methane and carbon dioxide emission rates were calculated by performing a linear regression on the differences of methane and carbon dioxide concentrations and adjusted for chamber volume and area covered. The following equation was used for the calculation (Rolston 1986; Yang and Chang 1997; Hegde et al. 2003):

$f=(V / A)(\Delta C / \Delta t)$

where, $f=$ methane or carbon dioxide emission rate $(\mathrm{mg}$ $\left.\mathrm{m}^{-2} \min ^{-1}\right), V=$ volume of chamber above the compost $\left(\mathrm{m}^{3}\right)$, $A=$ cross-section of chamber $\left(\mathrm{m}^{2}\right), \Delta C=$ concentration difference between time zero and time $\mathrm{t}\left(\mathrm{mg} \mathrm{m}^{-3}\right)$, and $\Delta t=$ time duration between two sampling periods ( $\mathrm{min}$ ) (Yang and Chang 1998).

\subsection{Effect of Accumulative Time and Composting Period on Methane and Carbon Dioxide Emissions}

Methane and carbon dioxide emissions from the com- 
(a)

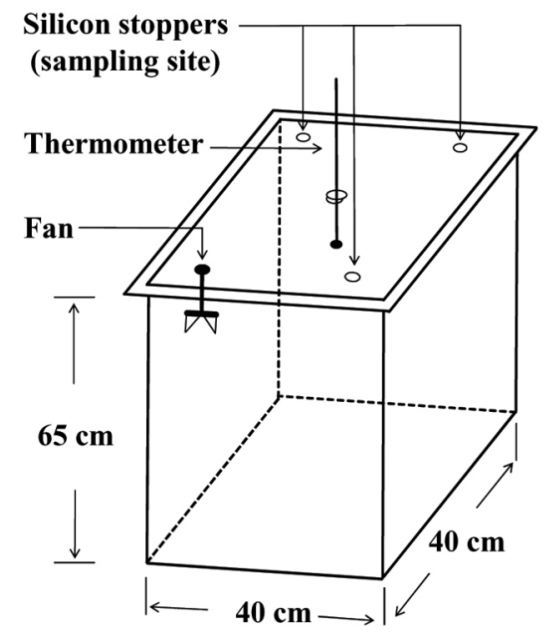

(b)

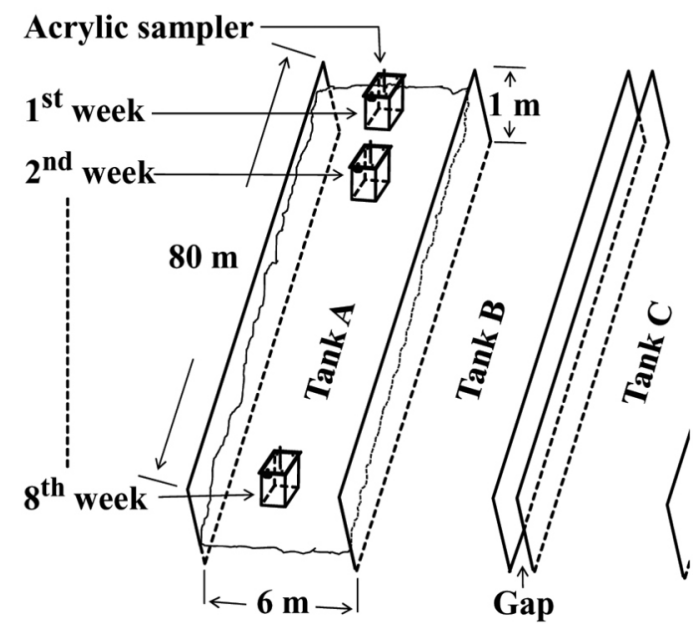

Fig. 1. The diagram of acrylic chamber and gas sampling on compost plants. (a) Acrylic chamber, (b) Arrangement of gas sampling on compost plants.

post were investigated as follows:

(1) Effect of accumulative time:

Methane and carbon dioxide emissions from compost were measured with the accumulative time of $0,5,10$, $15,20,30,40$, and $50 \mathrm{~min}$.

(2) Effect of composting period:

Methane and carbon dioxide emissions from compost were determined at 1 - to 8 -week composting periods.

\subsection{Germination Test}

After composting, a sample was extracted with five times of distilled water $\left(\mathrm{w} \mathrm{v}^{-1}\right)$ and shaken at $180 \mathrm{rpm}$ and $30^{\circ} \mathrm{C}$ for $30 \mathrm{~min}$. Three $\mathrm{ml}$ of an appropriate dilution of compost extract was added to filter paper (Whatman No. 1), which was placed in the Petri dish and then 25 alfalfa seeds were placed on the filter paper and incubated at $25^{\circ} \mathrm{C}$ for 5 days. Percentage of germination was counted at day 5 , and distilled water was used as the control (Pai et al. 2003).

\subsection{Analytical Methods}

Air and compost temperatures were determined on site directly or under $10 \mathrm{~cm}$ depth of compost with $\mathrm{Hg}$-thermometer. Compost $\mathrm{pH}$ was measured directly in tested composts or in $1: 1\left(\mathrm{w} \mathrm{v}^{-1}\right)$ compost to water suspension using a $\mathrm{pH}$ meter. Moisture content was determined by drying samples at $105^{\circ} \mathrm{C}$ to constant weight. Ash content was measured at $550^{\circ} \mathrm{C}$ for $24 \mathrm{~h}$. Total organic carbon was estimated using a TOC-5000A total organic carbon analyzer (Code HI 8424C, Shimadzu, Japan) (Hegde et al. 2003). Total nitrogen was determined with a modified Kjeldahl method (Yang et al. 1991). Experiments were carried out in triplicate. Data were subjected to analysis by the coefficient of variance and Dun- can's multiple range tests $(p=0.05)$ using the Statistical Analysis System (SAS Institute 2002).

\section{RESULTS AND DISCUSSION}

\subsection{Properties of Compost during Preparation}

Composting is the controlled decomposition of organic matter to stabilize and sanitize organic matter that can be used as soil conditioner and organic fertilizer in agriculture. During composting, temperature initially increased due to active decomposition of organic wastes and then decreased gradually with maturity. The moisture content, total organic carbon content and $\mathrm{C} / \mathrm{N}$ ratio decreased gradually while the $\mathrm{pH}$, ash content, total nitrogen content and germination rate increased (Table 1). After 7 - 8 weeks composting, the compost had moisture content of $25-26 \%$, total organic carbon $23-25 \%$, total nitrogen $2.9-3.1 \%, \mathrm{C} / \mathrm{N}$ ratio $7.5-8.4$ and a germination rate $98-99 \%$. This matches the standard requirement for organic fertilizer in Taiwan (Council of Agriculture/Taiwan 2003).

The initial height of compost was usually about $100 \mathrm{~cm}$ with the raw materials and about $50-60 \mathrm{~cm}$ with the final product. The compost temperature increased from the top surface to $50 \mathrm{~cm}$ depth and then decreased gradually to the bottom of the compost due to limited oxygen diffusion from the atmosphere into the compost and fermentation heat release from the bottom to the surface (Table 2). The temperature increases initially with high microbial activity and the easily available organic compounds are converted into biomass and heat by mesophilic zymogenous bacterial and fungal decomposers (Hellmann et al. 1997). The high temperatures prevailed above $60^{\circ} \mathrm{C}$ for 7 to 10 days, killing most pathogens and weeds - a requirement for good quality mature compost (Yang 1994, 2005a). During the thermophilic 
Table 1. Properties of compost during preparation.

\begin{tabular}{ccccccccc}
\hline $\begin{array}{c}\text { Composting } \\
\text { period (week) }\end{array}$ & $\begin{array}{c}\text { Temp. } \\
\left({ }^{\circ} \mathbf{C}\right)\end{array}$ & $\begin{array}{c}\text { Moisture } \\
\text { content }(\mathbf{\%})\end{array}$ & $\mathbf{p H}$ & $\begin{array}{c}\text { Ash } \\
\mathbf{( \% )}\end{array}$ & $\begin{array}{c}\text { TOC } \\
\mathbf{( \% )}\end{array}$ & $\begin{array}{c}\text { TN } \\
\mathbf{( \% )}\end{array}$ & $\begin{array}{c}\text { C/N } \\
\text { Germination } \\
\text { rate }(\%)\end{array}$ \\
\hline 1 & $54.3 \pm 1.5$ & $55.27 \pm 0.23$ & $6.84 \pm 0.07$ & $33.08 \pm 0.75$ & $42.58 \pm 1.59$ & $1.94 \pm 0.07$ & 21.98 & $30.0 \pm 5.0$ \\
2 & $57.5 \pm 0.5$ & $51.62 \pm 1.75$ & $7.49 \pm 0.04$ & $34.17 \pm 0.96$ & $36.93 \pm 0.92$ & $2.12 \pm 0.07$ & 17.45 & $62.2 \pm 8.0$ \\
3 & $61.0 \pm 1.0$ & $50.11 \pm 0.69$ & $8.10 \pm 0.02$ & $44.65 \pm 0.60$ & $34.86 \pm 2.38$ & $2.37 \pm 0.05$ & 14.71 & $85.2 \pm 10.5$ \\
4 & $54.3 \pm 2.5$ & $36.94 \pm 0.83$ & $8.54 \pm 0.03$ & $46.49 \pm 0.88$ & $30.85 \pm 1.75$ & $2.54 \pm 0.15$ & 12.15 & $83.7 \pm 3.4$ \\
5 & $50.3 \pm 2.1$ & $32.75 \pm 0.14$ & $8.71 \pm 0.02$ & $46.08 \pm 0.31$ & $28.23 \pm 0.57$ & $2.64 \pm 0.09$ & 10.69 & $91.9 \pm 9.3$ \\
6 & $49.7 \pm 1.5$ & $27.30 \pm 0.24$ & $8.70 \pm 0.01$ & $49.78 \pm 0.23$ & $25.72 \pm 0.69$ & $2.89 \pm 0.07$ & 8.90 & $92.6 \pm 3.4$ \\
7 & $33.3 \pm 1.0$ & $25.96 \pm 0.15$ & $8.81 \pm 0.02$ & $50.40 \pm 0.98$ & $24.70 \pm 0.43$ & $2.96 \pm 0.14$ & 8.34 & $98.5 \pm 1.3$ \\
8 & $29.5 \pm 1.0$ & $25.98 \pm 0.20$ & $8.77 \pm 0.01$ & $50.99 \pm 0.16$ & $23.12 \pm 1.03$ & $3.05 \pm 0.08$ & 7.58 & $99.3 \pm 1.2$ \\
\hline
\end{tabular}

*Means \pm S.D. $(n \geq 3)$

Table 2. Compost temperature at different depths and composting periods.

\begin{tabular}{|c|c|c|c|c|c|c|c|c|}
\hline \multirow{2}{*}{ Depth (cm) } & \multicolumn{8}{|c|}{ Composting period (week) } \\
\hline & 1 & 2 & 3 & 4 & 5 & 6 & 7 & 8 \\
\hline Compost height $(\mathrm{cm})$ & $93.7 \pm 12.7$ & $94.0 \pm 4.4$ & $70.0 \pm 2.9$ & $70.0 \pm 4.0$ & $75.0 \pm 2.1$ & $70.3 \pm 5.5$ & $50.3 \pm 2.1$ & $55.7 \pm 1.5$ \\
\hline Air temp. $\left({ }^{\circ} \mathrm{C}\right)$ & $18.9 \pm 0.4$ & $18.7 \pm 0.3$ & $18.2 \pm 0.3$ & $17.3 \pm 0.3$ & $17.6 \pm 0.3$ & $16.4 \pm 0.2$ & $15.5 \pm 0.2$ & $15.0 \pm 0.2$ \\
\hline \multicolumn{9}{|l|}{ Compost temp. $\left({ }^{\circ} \mathrm{C}\right)$} \\
\hline $0-10 \mathrm{~cm}$ depth & $54.3 \pm 1.5$ & $57.5 \pm 0.5$ & $61.0 \pm 1.0$ & $54.3 \pm 2.5$ & $50.3 \pm 2.1$ & $49.7 \pm 1.5$ & $33.3 \pm 1.0$ & $29.5 \pm 1.0$ \\
\hline $10-30 \mathrm{~cm}$ depth & $59.0 \pm 0.6$ & $63.9 \pm 1.0$ & $67.2 \pm 1.4$ & $63.1 \pm 0.5$ & $59.7 \pm 1.2$ & $55.9 \pm 1.1$ & $40.7 \pm 0.7$ & $45.7 \pm 0.8$ \\
\hline $30-50 \mathrm{~cm}$ depth & $62.6 \pm 1.9$ & $63.4 \pm 0.4$ & $67.7 \pm 0.6$ & $70.0 \pm 1.0$ & $70.3 \pm 0.6$ & $68.1 \pm 0.1$ & $55.7 \pm 0.6$ & $50.0 \pm 0.1$ \\
\hline $50-70 \mathrm{~cm}$ depth & $59.0 \pm 0.6$ & $62.8 \pm 0.7$ & $64.4 \pm 0.4$ & $69.1 \pm 0.2$ & $66.5 \pm 0.4$ & $66.4 \pm 0.5$ & - & - \\
\hline$>70 \mathrm{~cm}$ depth & $56.5 \pm 0.4$ & $63.0 \pm 0.6$ & - & - & - & - & - & - \\
\hline
\end{tabular}

*Means \pm S.D. $(n \geq 3)$

phase with temperatures above $60^{\circ} \mathrm{C}$, thermophilic microorganisms dominate, i.e., fungal populations decline (Herrmann and Shann 1997). During the subsequent mesophilic stage, actinomycetes remain and fungi reappear (Hellmann et al. 1997). After the easily degradable compounds are metabolized, the temperature decreases due to heat dissipation surpassing heat production (Jäckel et al. 2005). The temperature patterns and composition changes noted were similar to that in other well known compost plants for boiler (Yang et al. 2001; Yang and Chen 2003; Yang 2005a) and pile-type (Ekinci et al. 2000; Fukumoto et al. 2003) composting.

\subsection{Effect of Accumulative Time on Methane and Carbon Dioxide Concentrations and Emissions}

Effect of accumulative time on methane and carbon dioxide emissions in the closed acrylic chamber at different composting periods are shown in Table 3, Figs. 2, and 3. Methane and carbon dioxide emissions decreased gradually with the increasing of accumulative time. Methane concentration increased $4.50 \pm 0.37,11.49 \pm 0.17,1.01 \pm 0.02$, $0.16 \pm 0.01,0.46 \pm 0.07,0.12 \pm 0.04,0.12 \pm 0.03$, and 0.30 $\pm 0.01 \mathrm{ppm} \mathrm{min}^{-1}$ for $15 \mathrm{~min}$ accumulative time over the 1 to 8-week composting periods, respectively; while carbon dioxide concentration increased $160.7 \pm 5.5,155.1 \pm 9.2$, $204.0 \pm 2.1,113.9 \pm 0.9,107.7 \pm 1.4,91.7 \pm 1.5,44.6 \pm 1.5$, and $41.7 \pm 1.0 \mathrm{ppm} \mathrm{min}^{-1}$, respectively. Methane and carbon dioxide emissions increased slightly but with high fluctuation when the accumulative time was less than $10 \mathrm{~min}$ due to sampling error; however, the values decreased significantly when the accumulative time was more than $20 \mathrm{~min}$ for the repression of gas emission into the chamber. The ratios of methane emission for 15 min accumulative time to 10 min accumulative time were $0.94,0.97,0.99,1.00,0.98$, 
Table 3. Methane and carbon dioxide emissions with different accumulative times and composting periods.

\begin{tabular}{|c|c|c|c|c|c|c|c|c|}
\hline \multirow{2}{*}{$\begin{array}{c}\text { Accumulative } \\
\text { time (min) }\end{array}$} & \multicolumn{8}{|c|}{ Composting period (week) } \\
\hline & 1 & 2 & 3 & 4 & 5 & 6 & 7 & 8 \\
\hline \multicolumn{9}{|c|}{ (1) Methane emission rate $\left(\mathrm{ppm} \min ^{-1}\right)$} \\
\hline $0-5$ & $5.09 \pm 0.23$ & $12.38 \pm 0.27$ & $1.02 \pm 0.10$ & $0.17 \pm 0.01$ & $0.48 \pm 0.10$ & $0.13 \pm 0.10$ & $0.13 \pm 0.08$ & $0.32 \pm 0.03$ \\
\hline $0-10$ & $4.77 \pm 0.57$ & $11.90 \pm 0.92$ & $1.02 \pm 0.04$ & $0.16 \pm 0.00$ & $0.47 \pm 0.07$ & $0.12 \pm 0.03$ & $0.13 \pm 0.04$ & $0.32 \pm 0.02$ \\
\hline $0-15$ & $4.50 \pm 0.37$ & $11.49 \pm 0.17$ & $1.01 \pm 0.02$ & $0.16 \pm 0.01$ & $0.46 \pm 0.03$ & $0.12 \pm 0.04$ & $0.12 \pm 0.03$ & $0.30 \pm 0.01$ \\
\hline $0-20$ & $4.25 \pm 0.31$ & $10.81 \pm 0.60$ & $0.98 \pm 0.07$ & $0.15 \pm 0.01$ & $0.44 \pm 0.00$ & $0.11 \pm 0.02$ & $0.12 \pm 0.02$ & $0.29 \pm 0.00$ \\
\hline $0-30$ & $3.94 \pm 0.06$ & $10.19 \pm 0.65$ & $0.90 \pm 0.03$ & $0.14 \pm 0.00$ & $0.42 \pm 0.02$ & $0.10 \pm 0.02$ & $0.11 \pm 0.04$ & $0.28 \pm 0.00$ \\
\hline $0-40$ & $3.74 \pm 0.35$ & $9.25 \pm 0.05$ & $0.83 \pm 0.01$ & $0.13 \pm 0.00$ & $0.40 \pm 0.02$ & $0.10 \pm 0.01$ & $0.11 \pm 0.02$ & $0.28 \pm 0.00$ \\
\hline $0-50$ & $3.37 \pm 0.19$ & $8.25 \pm 0.11$ & $0.76 \pm 0.01$ & $0.12 \pm 0.00$ & $0.37 \pm 0.00$ & $0.09 \pm 0.01$ & $0.09 \pm 0.01$ & $0.25 \pm 0.01$ \\
\hline \multicolumn{9}{|c|}{ (2) Carbon dioxide emission rate $\left(\mathrm{ppm} \min ^{-1}\right)$} \\
\hline $0-5$ & $172.6 \pm 27.2$ & $163.4 \pm 19.4$ & $205.4 \pm 14.3$ & $118.6 \pm 13.8$ & $112.2 \pm 2.9$ & $101.8 \pm 7.1$ & $50.3 \pm 3.8$ & $42.7 \pm 4.3$ \\
\hline $0-10$ & $165.8 \pm 5.5$ & $155.8 \pm 9.2$ & $204.6 \pm 13.2$ & $116.6 \pm 2.1$ & $111.6 \pm 2.3$ & $94.9 \pm 2.6$ & $45.8 \pm 2.1$ & $42.4 \pm 2.6$ \\
\hline $0-15$ & $160.7 \pm 1.1$ & $155.1 \pm 4.3$ & $204.0 \pm 6.7$ & $113.9 \pm 0.9$ & $107.7 \pm 1.4$ & $91.7 \pm 1.5$ & $44.6 \pm 1.5$ & $41.7 \pm 1.0$ \\
\hline $0-20$ & $155.0 \pm 0.8$ & $144.8 \pm 1.6$ & $188.7 \pm 4.2$ & $108.1 \pm 3.8$ & $103.0 \pm 1.7$ & $86.5 \pm 0.5$ & $42.4 \pm 0.0$ & $40.7 \pm 2.0$ \\
\hline $0-30$ & $139.3 \pm 2.2$ & $133.8 \pm 5.7$ & $171.2 \pm 6.7$ & $101.3 \pm 1.0$ & $95.2 \pm 0.4$ & $82.4 \pm 1.4$ & $39.9 \pm 1.5$ & $38.6 \pm 1.3$ \\
\hline $0-40$ & $119.7 \pm 2.0$ & $117.1 \pm 4.6$ & $150.9 \pm 2.1$ & $92.7 \pm 1.0$ & $87.9 \pm 0.9$ & $77.3 \pm 0.8$ & $38.2 \pm 1.4$ & $36.4 \pm 0.8$ \\
\hline $0-50$ & $107.0 \pm 0.8$ & $99.9 \pm 0.3$ & $125.4 \pm 0.5$ & $82.3 \pm 1.0$ & $79.1 \pm 0.7$ & $71.5 \pm 0.3$ & $34.3 \pm 1.2$ & $33.8 \pm 0.3$ \\
\hline
\end{tabular}

*Means \pm S.D. $(n \geq 3)$

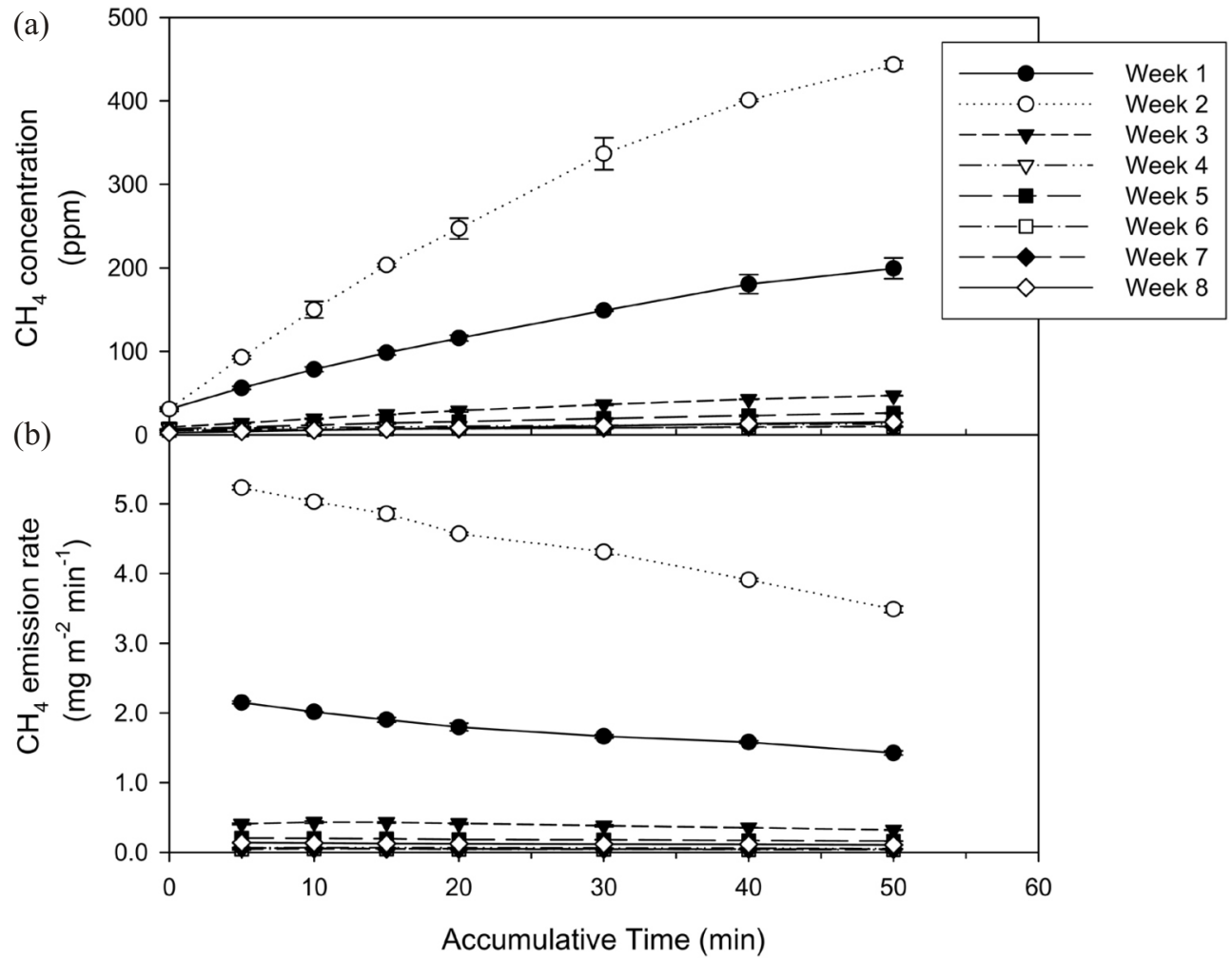

Fig. 2. Methane concentration and emission rate with different accumulative times during composting for 1 to 8 weeks. (a) Concentration, (b) Emission rate. 


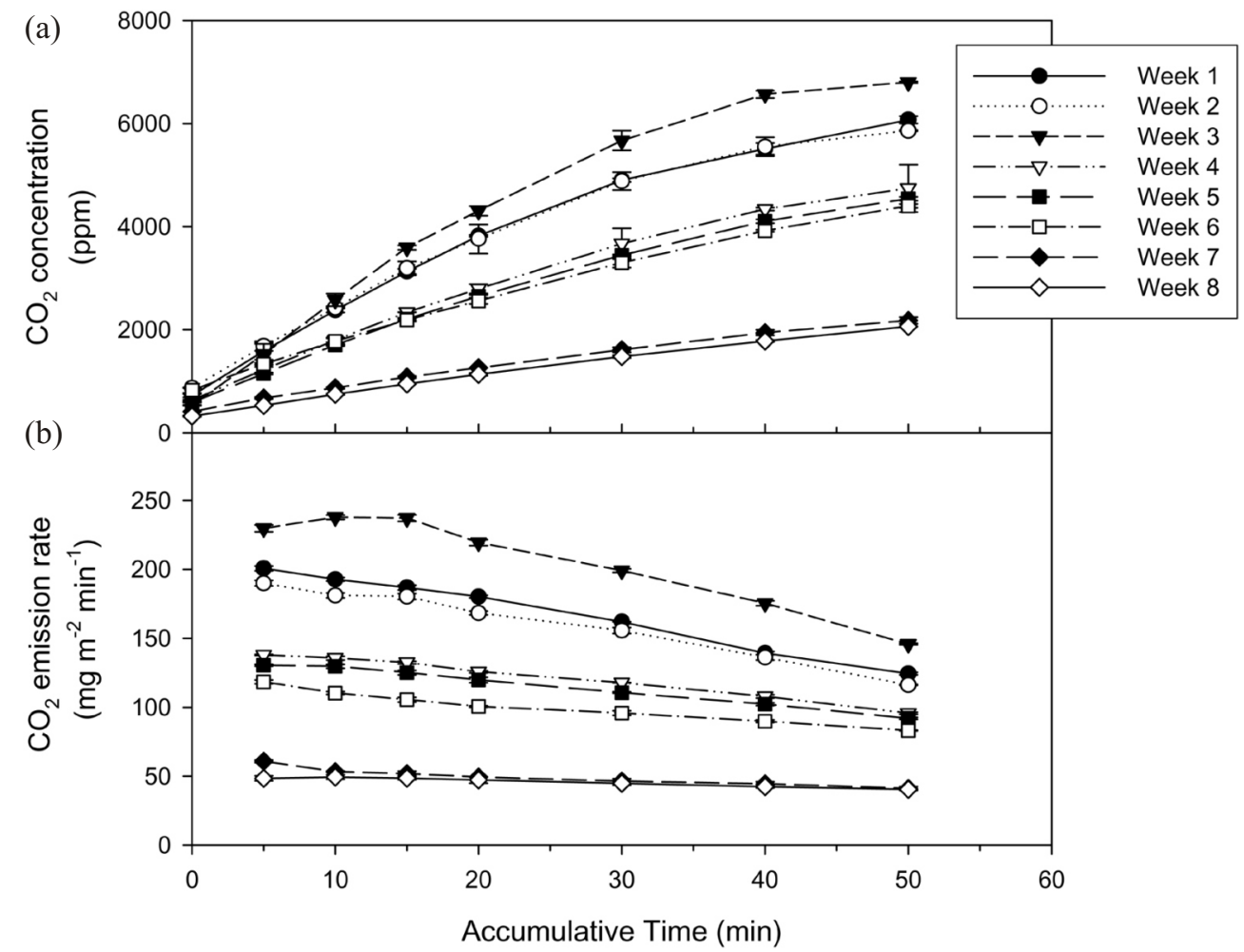

Fig. 3. Carbon dioxide concentration and emission rate with different accumulative times during composting for 1 to 8 weeks. (a) Concentration, (b) Emission rate.

$1.00,0.92$, and 0.94 at 1 to 8 weeks of composting, respectively while the ratios for $20 \mathrm{~min}$ accumulative time to 15 min accumulative time were $0.94,0.94,0.97,0.94,0.96$, $0.92,1.00$, and 0.97 , respectively. The ratios of carbon dioxide emission for $15 \mathrm{~min}$ accumulative time to $10 \mathrm{~min}$ accumulative time were $0.97,0.99,1.00,0.98,0.97,0.97$, 0.97 , and 0.98 at 1 to 8 weeks of composting, respectively while the ratios for $20 \mathrm{~min}$ accumulative time to $15 \mathrm{~min}$ accumulative time were $0.96,0.94,0.93,0.95,0.96,0.94$, 0.95 , and 0.98 , respectively.

Thirty min accumulative time with a closed acrylic chamber was used in paddy fields, wetlands and landfills with low temperature and low to intermediate emission rates (Yang and Chang 1997; Chang and Yang 2003; Hegde et al. 2003); however, in compost preparations with high temperature and high emission rate, $15 \mathrm{~min}$ accumulative time was appropriate for more reliable measurement and less repression of gas emission in the chamber. The methane emission rate decreased 7 - 17\% when 30 min accumulative time was used instead of $15 \mathrm{~min}$ accumulative time while the carbon dioxide emission rate also decreased $7-16 \%$. The fluctuations of methane and carbon dioxide emission rates were high when accumulative time was less than $10 \mathrm{~min}$ for sampling error. Therefore, $15 \mathrm{~min}$ accumulative time was chosen in this study for practical determinations and accuracy measurements.

\subsection{Effect of Composting Period on Methane and Carbon Dioxide Concentrations and Emissions}

The effect of the composting period on methane and carbon dioxide concentrations and emission rates in the closed acrylic chamber are shown in Table 3, Figs. 2, and 3. Atmospheric methane concentrations were: $17.5 \pm 0.1,22.1 \pm 0.6$, $9.2 \pm 0.1,7.7 \pm 0.0,5.7 \pm 0.2,6.0 \pm 0.0,5.5 \pm 0.2$, and $3.4 \pm$ $0.4 \mathrm{ppm}$ at 1 to 8 weeks of composting, respectively. Methane concentrations in the closed acrylic chamber with $15 \mathrm{~min}$ accumulative time were: $98.4 \pm 2.8,203.3 \pm 2.1,24.4 \pm 0.3$, $9.5 \pm 0.1,14.0 \pm 1.0,7.1 \pm 0.3,6.9 \pm 0.2$, and $6.9 \pm 0.1 \mathrm{ppm}$ at 1 to 8 weeks of composting, respectively while methane emission rates were: $1.90 \pm 0.16,4.86 \pm 0.07,0.43 \pm 0.01$, $0.07 \pm 0.00,0.20 \pm 0.03,0.05 \pm 0.02,0.05 \pm 0.01$, and $0.13 \pm$ $0.00 \mathrm{mg} \mathrm{m}^{-2} \mathrm{~min}^{-1}$, respectively.

Methane emission was the highest at the 2-week composting period and decreased sharply after 3 to 4 weeks of composting. Methane concentrations in the atmosphere and in the sampling chamber, and the methane emission rate reached their peaks near the end of second week due to active microbial growth and organic matter degradation. The total organic carbon content was $42.58 \%$ at 1 week of composting, $36.93 \%$ at 2 weeks of composting, and $34.86 \%$ at 3 weeks of composting (Table 1). Decrease in total organic carbon was the highest at the second week of composting, 
which is consistent with peak of methane emission. The patterns of methane emission were similar to the reports of Osada et al. (2000) in the swine waste composting process, Kuroda et al. (1996) and Fukumoto et al. (2003) in swine feces composting and swine manure composting. Methane emission was high during the first period of composting and decreased gradually during the composting process. Changing the scale of compost pile was a major cause of the difference in emission patterns. The number and size of anaerobic sites inside the composting material are major factors in methane emission. During composting of livestock waste without forced aeration, anaerobic sites are established in the center of the heap due to less air exchange than in the surface portions, and a large-scale compost pile will increase the number and size of anaerobic sites in the pile (Fukumoto et al. 2003). Therefore, changing the scale of the compost pile and turning operations may change the emission rates of gaseous components.

In the case of carbon dioxide, atmospheric concentrations were: $732.9 \pm 4.4,745.0 \pm 15.4,760.3 \pm 18.5,579.3 \pm$ $17.2,557.4 \pm 16.8,471.8 \pm 16.8,392.7 \pm 3.2$, and $394.5 \pm$ $7.7 \mathrm{ppm}$ at 1 to 8 weeks for the composting area, respectively. Carbon dioxide concentrations in the closed acrylic chamber for $15 \mathrm{~min}$ accumulative time were: $3132.2 \pm 40.3$, $3194.1 \pm 34.5,3593.7 \pm 31.5,2339.2 \pm 2.0,2205.0 \pm 24.9$, $2189.3 \pm 30.8,1082.5 \pm 19.4$, and $950.7 \pm 2.4 \mathrm{ppm}$ at 1 to 8 weeks of composting, respectively; while, carbon dioxide emission rates were: $186.8 \pm 6.4,180.3 \pm 10.7,237.2 \pm 2.4$, $132.4 \pm 1.0,125.2 \pm 1.7,105.5 \pm 1.7,51.9 \pm 1.7$, and $48.5 \pm$ $1.1 \mathrm{mg} \mathrm{m}^{-2} \mathrm{~min}^{-1}$, respectively. The increases in carbon dioxide concentrations probably originated from active micro- bial decomposition of easily degradable substrates such as sugars and proteins (Beck-Friis et al. 2001). The carbon dioxide emission rate reached its peak near the end of the third week and then decreased sharply after 4 to 6 weeks of composting because of a reduction in microbial activity due to limited readily available degradable compounds. Carbon dioxide emissions from compost and stockpiled dairy cattle manure were also high initially and decreased with time (Pattey et al. 2005). The production of carbon dioxide results mainly from the oxidation of easily degradable carbon compounds and the activity of microorganisms.

The correlations between compost properties and methane or carbon dioxide emissions are summarized in Table 4. Methane emission had positive correlation with moisture content, $\mathrm{C} / \mathrm{N}$ ratio, total organic carbon, carbon dioxide emission and temperature; significantly negative correlation with $\mathrm{pH}$, and ash content; negative correlation with total nitrogen and the germination rate. Carbon dioxide emission had very significantly positive correlation with temperature, moisture content, and total organic carbon; significantly positive correlation with $\mathrm{C} / \mathrm{N}$ ratio; very significantly negative correlation with total nitrogen; negative correlation with $\mathrm{pH}$, ash content, and germination rate. The temperature, moisture content, total organic carbon, and total nitrogen are the major factors influencing methane and carbon dioxide emissions during composting. Total nitrogen content, $\mathrm{pH}$, ash content and germination rate had negative correlation with both carbon dioxide and methane emissions during composting. Therefore, adjustment of the appropriate $\mathrm{C} / \mathrm{N}$ ratio may shorten the maturity period of composting and reduce the carbon dioxide and methane emissions during composting. Carbon dioxide emis-

Table 4. Correlation coefficient (R) between greenhouse gases emissions and compost properties.

\begin{tabular}{|c|c|c|c|c|c|c|c|c|c|}
\hline Parameter & $\begin{array}{c}\mathrm{CH}_{4} \\
\text { Emission rate } \\
\left(\mathrm{mg} \mathrm{m}^{-2} \mathrm{~min}^{-1}\right)\end{array}$ & $\begin{array}{c}\mathrm{CO}_{2} \\
\text { Emission rate } \\
\left(\mathrm{mg} \mathrm{m}^{-2} \mathrm{~min}^{-1}\right)\end{array}$ & $\begin{array}{c}\text { Temp. } \\
\left({ }^{\circ} \mathrm{C}\right)\end{array}$ & $\begin{array}{c}\text { Moisture } \\
\text { content } \\
(\%)\end{array}$ & pH & $\begin{array}{l}\text { Ash } \\
\text { (\%) }\end{array}$ & $\begin{array}{c}\text { TOC } \\
(\%)\end{array}$ & $\begin{array}{l}\text { TN } \\
(\%)\end{array}$ & $\mathbf{C} / \mathbf{N}$ \\
\hline $\begin{array}{l}\mathrm{CO}_{2} \\
\text { Emission rate } \\
\left(\mathrm{mg} \mathrm{m}^{-2} \min ^{-1}\right)\end{array}$ & 0.454 & & & & & & & & \\
\hline Temp. $\left({ }^{\circ} \mathrm{C}\right)$ & 0.416 & $0.921 * *$ & & & & & & & \\
\hline Moisture content (\%) & 0.675 & $0.907 * *$ & $0.773^{*}$ & & & & & & \\
\hline $\mathrm{pH}$ & $-0.719^{*}$ & -0.696 & -0.560 & $-0.913 * *$ & & & & & \\
\hline Ash (\%) & $-0.833^{*}$ & -0.697 & -0.624 & $-0.907 * *$ & $0.959 * *$ & & & & \\
\hline TOC (\%) & 0.639 & $0.846^{* *}$ & $0.748^{*}$ & $0.975 * *$ & $-0.953 * *$ & $-0.938 * *$ & & & \\
\hline $\mathrm{TN}(\%)$ & -0.696 & $-0.848 * *$ & $-0.781^{*}$ & $-0.971 * *$ & $0.931 * *$ & $0.956 * *$ & $-0.990 * *$ & & \\
\hline $\mathrm{C} / \mathrm{N}$ & 0.670 & $0.792^{*}$ & 0.686 & $0.958 * *$ & $-0.977 * *$ & $-0.959 * *$ & $0.994 * *$ & $-0.983 * *$ & \\
\hline Germination rate (\%) & -0.631 & -0.604 & -0.523 & $-0.838 * *$ & $0.972 * *$ & $0.932 * *$ & $-0.926 * *$ & $0.903 * *$ & $-0.957 * *$ \\
\hline
\end{tabular}

$* p<0.05 ; * * p<0.01$. 
sions from composting and stockpiled manure were also positively correlated with manure temperatures, which were higher than ambient temperatures (Pattey et al. 2005).

Pearson correlation coefficients between carbon dioxide emission and compost temperature, moisture content and total organic carbon were $0.921,0.907$, and 0.846 , respectively. The relationships between carbon dioxide emission and temperature, moisture content, total organic carbon by ANOVA and the multiple regression methods revealed that carbon dioxide emission (y) was significantly related to temperature $\left(\mathrm{x}_{1}\right)$, moisture content $\left(\mathrm{x}_{2}\right)$, and total organic carbon $\left(x_{3}\right)$. The regression equation is: $y=3.11907 x_{1}+6.19236 x_{2}$ $6.63081 \mathrm{x}_{3}-50.62498$. A coefficient of multiple determinations $\left(\mathrm{R}^{2}\right), 0.965$, suggests that correlation exists between the compost quality parameters and the carbon dioxide emission. The significance level $(0.0023)$ of the $F$ test in the ANOVA table was lower than $\alpha$ of 0.05 , which indicates that the compost properties should have a regressive correlation with the carbon dioxide emission. The Independent-Sample $t$ tests were also used to assess the significance of the coefficients between the means of two independent samples. A common rule of thumb is to drop the variable from the equation if its significance level ( $p$ value) is at $\leqq 0.05$. Extra sampling data were collected to examine the feasibility of the developed multiple regression equations. The results indicate that the carbon dioxide flux from various sampling sites was consistent with the simulation equation, and with a maximal deviation of $12.84 \%$. The same method was also applied to the relationships between methane emission and moisture content, total organic carbon and $\mathrm{C} / \mathrm{N}$ ratio. A coefficient of multiple determinations $\left(\mathrm{R}^{2}\right), 0.696$, suggests that a correlation exists between the methane emission and the compost quality parameters. However, the Pearson correlation coefficient between methane emission and compost parameters were lower than 0.7 . The significance level $(0.1546)$ of the $F$ test in the ANOVA table was higher than $\alpha$ of 0.05 , indicating that the methane emission was not related to compost properties in all stages. Methane emission was high in the initial stage of composting and then decreased sharply. The regression equation between methane emission ( $\left.\mathrm{y}^{\prime}\right)$ and moisture content $\left(\mathrm{x}_{2}\right), \mathrm{pH}\left(\mathrm{x}_{4}\right), \mathrm{C} / \mathrm{N}$ ratio $\left(\mathrm{x}_{5}\right)$, and ash content $\left(\mathrm{x}_{6}\right)$ is: $\mathrm{y}^{\prime}=0.13225 \mathrm{x}_{2}-0.97046 \mathrm{x}_{4}-1.10599 \mathrm{x}_{5}$ $0.55220 \mathrm{x}_{6}+50.77057$ in the initial composting stage (weeks 1 to 3 ); while, the equation is: $\mathrm{y}^{\prime}=0.02824 \mathrm{x}_{2}-0.0037 \mathrm{x}_{4}$ $0.1499 \mathrm{x}_{5}-0.07013 \mathrm{x}_{6}+4.13589$ in the later composting stage (weeks 4 to 8 ) with a maximal deviation of $16.25 \%$. In this study, the experimental results suggest that the emissions of carbon dioxide and methane from compost can be predicted using the regression equations developed here. Moreover, greenhouse gas emissions may be reduced by manipulating the appropriate factors.

In Taiwan, there were 55 compost plants with automatic turning operating once every 3 - 4 days for livestock manures, agricultural wastes and food processing residues treatment. Each year $8.0 \times 10^{5}$ ton of wastes are treated and $4.0 \times 10^{5}$ ton of composts are produced for agricultural use (Council of Agriculture/Taiwan 2007). There is potential for mitigating methane and carbon dioxide emissions during composting. Strategies to reduce methane and carbon dioxide emissions may be oriented toward: (1) adjustment the appropriate $\mathrm{C} / \mathrm{N}$ ratio of raw materials, (2) adjustment the appropriate moisture content with bulking materials, and (3) increasing methane oxidation with appropriate turning operations and aeration. Reducing of greenhouse gases emissions could be achieved through the adjustment of moisture content and the $\mathrm{C} / \mathrm{N}$ ratio of the substrate, appropriate turning operation and aeration during the composting.

In conclusion, composting functions as a bioreactor to control and manage the biodegradation of organic materials. Estimation of greenhouse gas emissions associated with livestock manure and agricultural waste handling requires the measurement of emission rates during treatment. The appropriate accumulative time for the measurement of methane and carbon dioxide emissions with a closed acrylic chamber was $15 \mathrm{~min}$. Methane and carbon dioxide emissions had high values at the first stage of composting and then these decreased gradually towards the maturity of compost. Adjustments in the appropriate $\mathrm{C} / \mathrm{N}$ ratio and moisture content of raw materials may shorten the maturity period of compost and reduce the carbon dioxide and methane emissions during composting.

Acknowledgements The authors thank Professors C. M. Lai, Y. C. Chung, and E. H. Chang for their technical assistances and helpful comments, and the National Science Council and Environmental Protection Administration of Taiwan for financial support (NSC 93-EPA-Z002008 and NSC 94-EPA-Z002-012).

\section{REFERENCES}

Amon, B., T. Amon, J. Boxberger, and C. Alt, 2001: Emissions of $\mathrm{NH}_{3}, \mathrm{~N}_{2} \mathrm{O}$ and $\mathrm{CH}_{4}$ from dairy cows housed in a farmyard manure tying stall (housing, manure storage, manure spreading). Nutr. Cycl. Agroecosyst., 60, 103-113, doi: 10.1023/A:1012649028772. [Link]

Beck-Friis, B., S. Smårs, H. Jönsson, and H. Kirchmann, 2001: Gaseous emissions of carbon dioxide, ammonia and nitrous oxide from organic household waste in a compost reactor under different temperature regimes. J. Agric. Eng. Res., 78, 423-430, doi: 10.1006/jaer.2000.0662. [Link]

Bogner, J. E., K. A. Spokas, and E. A. Burton, 1999: Temporal variations in greenhouse gas emissions at a midlatitude landfill. J. Environ. Qual., 28, 278-288.

Chang, T. C. and S. S. Yang, 2003: Methane emission from wetlands in Taiwan. Atmos. Environ., 37, 4551-4558, doi: 10.1016/S1352-2310(03)00588-0. [Link]

Chen, I. C., U. Hegde, C. H. Chang, and S. S. Yang, 2008: Methane and carbon dioxide emissions from closed land- 
fill in Taiwan. Chemosphere, 70, 1484-1491, doi: 10.1016/ j.chemosphere.2007.08.024. [Link]

Council of Agriculture, 2003: Compost of Livestocks, Kind and Standard of Fertilizer. Council of Agriculture, Taipei, Taiwan.

Council of Agriculture, 2007: Annual Report of Agricultural Production-2006. Council of Agriculture, Taipei, Taiwan.

Ekinci, K., H. M. Keener, and D. L. Elwell, 2000: Composting short paper tiber with boiler litter and additives. Part I: Effects of initial $\mathrm{pH}$ and carbon/nitrogen ratio on ammonia emission. Compost Sci. Utiliz., 8, 160-172.

Ekinci, K., H. M. Keener, and D. L. Elwell, 2002: Composting short paper fiber with boiler litter and additives. II. Evaluation and optimization of decomposition rate versus mixing ratio. Compost Sci. Utiliz., 10, 16-28.

Fukumoto, Y., T. Osada, D. Hanajima, and K. Haga, 2003: Patterns and quantities of $\mathrm{NH}_{3}, \mathrm{~N}_{2} \mathrm{O}$ and $\mathrm{CH}_{4}$ emissions during swine manure composting without forced aeration - effect of compost pile scale. Biores. Technol., 89, 109-114, doi: 10.1016/S0960-8524(03)00060-9. [Link]

Hao, X., C. Chang, F. J. Larney, and G. R. Travis, 2001: Greenhouse gas emissions during cattle feedlot manure composting. J. Environ. Qual., 30, 376-386.

Hao, X., C. Chang, and F. J. Larney, 2004: Carbon, nitrogen balances and greenhouse gas emission during cattle feedlot manure composting. J. Environ. Qual., 33, 37-44.

Hegde, U., T. C. Chang, and S. S. Yang, 2003: Methane and carbon dioxide emissions from Shan-Chu-Ku landfill site in northern Taiwan. Chemosphere, 52, 1275-1285, doi: 10.1016/S0045-6535(03)00352-7. [Link]

Hellmann, B., L. Zelles, A. Paloiarvi, and Q. Bai, 1997: Emission of climate-relevant trace gases and succession of microbial communities during open-window composting. Appl. Environ. Microbiol., 63, 1011-1018.

Herrmann, R. F. and J. F. Shann, 1997: Microbial community changes during the composting of municipal solid waste. Microb. Ecol., 33, 78-85, doi: 10.1007/s002489900010. [Link]

IPCC (Intergovernmental Panel on Climate Change), 2001: Climate Change 2001: The Scientific Basis. Cambridge University Press, Cambridge, UK.

Jäckel, U., K. Thummes, and P. Kämpfer, 2005: Thermophilic methane production and oxidation in compost. FEMS Microbiol. Ecol., 52, 175-184, doi: 10.1016/j.femsec.2004. 11.003. [Link]

Jang, H. D. and S. S. Yang, 2001: Greenhouse gases emission from municipal solid wastes in the column bioreactor. $J$. Biomass Energy Soc. China, 20, 101-112.

Khan, R. Z., C. Müller, and S. G. Sommer, 1997: Micrometeorological mass balance technique for measuring $\mathrm{CH}_{4}$ emission from stored cattle slurry. Biol. Fertil. Soils, 24, 442-444, doi: 10.1007/s003740050270. [Link]

Külling, D. R., F. Dohme, H. Menzi, F. Sutter, P. Lischer, and M. Kreuzer, 2002: Methane emissions of differently fed dairy cows and corresponding methane and nitrogen emis- sions from their manure during storage. Environ. Monit. Assess., 79, 129-150, doi: 10.1023/A:1020248700255. [Link]

Kumar, S., S. A. Gaikwad, A. V. Shekdar, P. S. Kshirsagar, and R. N. Singh, 2004: Estimation method for national methane emission from solid waste landfills. Atmos. Environ., 38, 3481-3487, doi: 10.1016/j.atmosenv.2004.02.057. [Link]

Kuroda, K., T. Osada, M. Yonapa, A. Kanematu, T. Nitta, S. Mouri, and T. Kojima, 1996: Emissions of malodorous compounds and greenhouse gases from composting swine feces. Biores. Technol., 56, 265-271, doi: 10.1016/09608524(96)00047-8. [Link]

Lindau, C. W., P. K. Bollich, R. D. DeLaune, A. R. Mosier, and K. F. Bronson, 1993: Methane mitigation in flooded Louisiana rice fields. Biol. Fertil. Soil., 15, 174-178, doi: 10.1007/BF00361607. [Link]

Meraz, R.-L., A.-M. Vidales, and A. Dominguez, 2004: A fractal-like kinetics equation to calculate landfill methane production. Fuel, 83, 73-80, doi: 10.1016/S0016-2361(03) 00212-6. [Link]

Osada, T., K. Kuroda, and M. Yonaga, 2000: Determination of nitrous oxide, methane, and ammonia emissions from a swine waste composting process. J. Mater. Cycles Waste Manag., 2, 51-56, doi: 10.1007/s10163-999-0018-1. [Link]

Pai, C. R., C. F. Wu, R. Y. Sun, C. B. Wei, and S. S. Yang, 2003: Composition analysis of livestock and poultry wastes during composting. J. Biomass Energy Soc. China, 22, 57-71.

Pattey, E., M. K. Trzcinski, and R. L. Desjardins, 2005: Quantifying the reduction of greenhouse gas emissions as a result of composting dairy and beef cattle manure. Nutr. Cycl. Agroecosyst., 72, 173-187, doi: 10.1007/s10705-005-12685. [Link

Rolston, D. E., 1986: Gas flux. In: Klute, A. (Ed.), Methods of Soil Analysis, $2^{\text {nd }}$ edition, American Society of Agronomy and Soil Science Society, American Monograph No. 9, Wisconsin, USA, 1103-1119.

SAS Institute, 2002: SAS/STAT User's Guide, Release 6.03 SAS Institute, Cary, North Carolina, USA.

Simpson, I. J., F. S. Rowland, S. Meinardi, and D. R. Blake, 2006: Influence of biomass burning during recent fluctuations in the slow growth of global tropospheric methane. Geophys. Res. Lett., 33, L22808, doi: 10.1029/2006GL 027330. [Link]

Sommer, S. G. and H. B. Møller, 2000: Emission of greenhouse gases during composting of deep litter from pig production - Effect of straw content. J. Agric. Sci., 134, 327-335, doi: 10.1017/S0021859699007625. [Link]

Su, J. J., B. Y. Liu, and Y. C. Chang, 2003: Emission of greenhouse gas from livestock waste and wastewater treatment in Taiwan. Agric. Ecosyst. Environ., 95, 253-263, doi: 10.1016/S0167-8809(02)00090-7. [Link]

US Environmental Protection Agency, 2002: Greenhouse Gases and Global Warming Potential Values. Excerpt from the Inventory of US Greenhouse Gases Emissions and Sinks: 1990-2000, 16 pp, http://www.epa.gov/global- 
warming/publications/emissions.

Yang, S. S., 1994: Composts and agricultural production in Taiwan. Soil Fertil. Taiwan, 29-62.

Yang, S. S., 2005a: Management of composting. In: Chen, Z. S. and C. Bejosano-Gloria (Eds.), Compost Production: A Manual for Asian Farmers, Food \& Fertilizer Technology Center, Taipei, Taiwan, 45-63.

Yang, S. S., 2005b: Methane and nitrous oxide emission from animal feeding sector in Taiwan during 1990 to 2003. In: Liu, C. M. (Ed.), Progress in Climate Change, Impact, Adaptation and Sustainable Development Research, 2005, Part 2. Global Change Research Center of National Taiwan University, Environmental Research Center of National Central University, and Sustainable Development Research Promotion Committee of National Science Council, Taipei, Taiwan, 565-575.

Yang, S. S. and E. H. Chang, 1997: Effect of fertilizer application on methane emission/production in the paddy soils of Taiwan. Biol. Fertil. Soils, 25, 245-251, doi: 10.1007/ s003740050310. [Link]

Yang, S. S. and H. L. Chang, 1998: Effect of environmental conditions on methane production and emission from paddy soil. Agric. Ecosyst. Environ., 69, 69-80, doi: 10.1016/ S0167-8809(98)00098-X. [Link]

Yang, S. S. and K. S. Chen, 2003: Application of thermophilic microbes for preparing biofertilizers. Plant Prot. Bullet. Spec. Publ. New, 5, 267-291.
Yang, S. S., S. L. Chang, C. B. Wei, and H. C. Lin, 1991: Reduction of waste production in the Kjeldahl method. J. Biomass Energy Soc. China, 10, 147-155.

Yang, S. S., H. T. Yang, W. R. Chen, and C. B. Wei, 2001: Properties of livestock and poultry wastes during composting in the farms of northern Taiwan. J. Chinese Environ. Soc., 24, 8-25.

Yang, S. S., C. M. Liu, C. M. Lai, and Y. L. Liu, 2003a: Estimation of methane and nitrous oxide emission from paddy fields and uplands during 1990-2000 in Taiwan. Chemosphere, 52, 1295-1305, doi: 10.1016/S0045-6535(03) 00029-8. [Link]

Yang, S. S., C. M. Liu, and Y. L. Liu, 2003b: Estimation of methane and nitrous oxide emission from animal production sector in Taiwan during 1990-2000. Chemospere, 52, 1381-1388, doi: 10.1016/S0045-6535(03)00473-9. [Link]

Yang, S. S., C. P. Liu, C. M. Lai, J. J. Horng, Y. C. Lin, I. C. Chen, and C. B. Wei, 2005: Estimation of methane and nitrous oxide emissions from paddy fields during 1990 to 2003 in Taiwan with local measurement and IPCC method. In: Liu, C. M. (Ed.), Progress in Climate Change, Impact, Adaptation and Sustainable Development Research, 2005, Part 2. Global Change Research Center of National Taiwan University, Environmental Research Center of National Central University, and Sustainable Development Research Promotion Committee of National Science Council. Taipei, Taiwan, 545-554. 